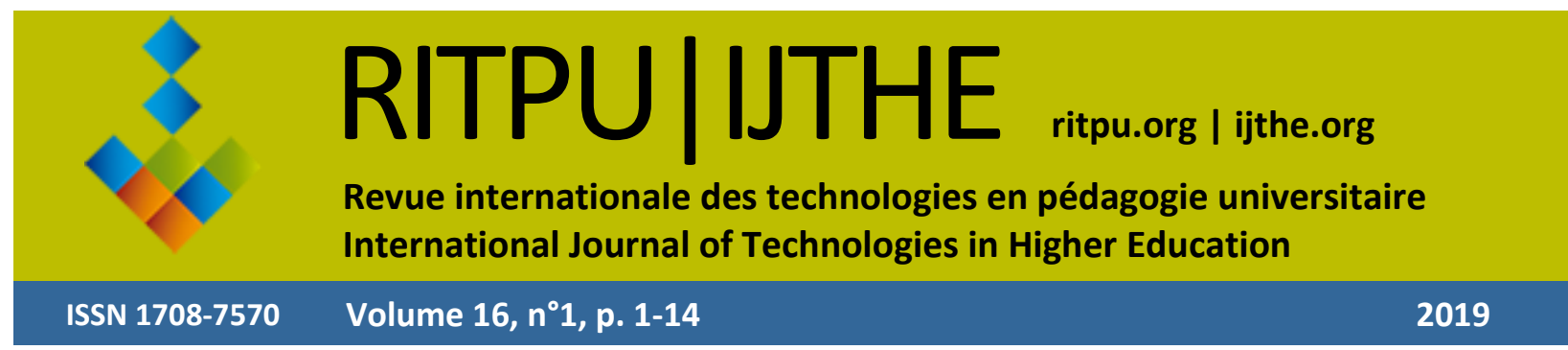

\title{
Between continuity and change: $A$ comparison of technology use by pre- and post-migration international students and local students
}

Simon COLLIN

Université du Québec à Montréal

Canada

collin.simon@uqam.ca

Thierry KARSENTI

Université de Montréal

Canada

Entre continuité et changement : usages

technologiques pré- et post-migratoires des étudiants

internationaux et comparaison avec les étudiants

locaux

https://doi.org/10.18162/ritpu-2019-v16n1-01

\begin{abstract}
Despite the growing number of studies on migrants' use of technology, few have focused on the case of international students. Because they come from different countries where they have developed variable uses of technology according to country-specific cultural, political, economic, and other factors, international students may have to adapt the way they use technologies in response to new academic and relational customs and demands at their host university. Based on the idea that their technology use after migration is necessarily influenced by the uses they had developed before migration, this article's objective is to draw a portrait of technology use by international students before and after migration, and in comparison to local students. A sample of 1,325 international students and 251 local students attending two Canadian universities responded to questionnaires, and the responses were analyzed statistically. The results indicate that, overall, international students increase their use of technologies after migration. Some changes observed are associated with student life in general and university studies in particular - they are thus valid for all students, whether or not they are international, while others appear to be attributable to migration and differentiate international students from their local peers. This study contributes to the advancement of knowledge in that it constitutes a first step toward a more nuanced understanding of the role that technology plays in the university integration of international students.
\end{abstract}

\section{Keywords}

International students; migration; technology use; access to technology; university 


\section{Résumé}

Bien qu'un nombre croissant d'études s'intéresse aux usages technologiques des migrants, peu se sont focalisées sur le cas des étudiants internationaux. Parce qu'ils sont issus de différents pays, dans lesquels ils ont développés des usages technologiques variables selon des facteurs culturels, politiques, économiques, etc. propres à chaque pays d'origine, les étudiants internationaux sont susceptibles d'adapter leurs usages technologiques pour répondre aux nouvelles modalités académiques et relationnelles de leur université d'accueil. Sur l'idée que les usages technologiques des migrants après la migration sont nécessairement influencés par ceux qu'ils ont développés avant la migration, cet article a pour objectif de comparer les usages technologiques des étudiants internationaux avant et après leur migration et par rapport à ceux des étudiants locaux. Un échantillon de 1325 étudiants internationaux et de 251 étudiants locaux de deux universités canadiennes ont répondu à un questionnaire qui a fait l'objet d'analyses statistiques. Les résultats indiquent que, dans l'ensemble, les usages technologiques des étudiants augmentent après leur migration. Certains changements observés sont associés à la vie étudiante en général et aux études universitaires en particulier - ils sont alors valables pour l'ensemble des étudiants, qu'ils soient internationaux ou non - alors que d'autres semblent attribuables à la migration et distinguent les étudiants internationaux de leurs pairs locaux. Par sa contribution scientifique, cette étude représente une première et nécessaire étape visant à mieux comprendre le rôle des technologies dans l'intégration universitaire des étudiants internationaux.

\section{Mots clés}

Étudiants internationaux; migration; usages technologiques; accès aux technologies; université.

\section{Introduction}

Information and communication technology (hereinafter, technology) promises to be an integral aspect of the migration process for the foreseeable future. Since the 1990s, researchers have paid this new development increasing attention, and this has intensified since the 2000s (Mattelart, 2009; Rigoni, 2010). Yet, of the many studies investigating migrants' technology use, few have considered the particular case of international students. Defined as "students who have crossed a national or territorial border for the purpose of education and are now enrolled outside their country of origin" (International [or internationally mobile] students, n.d.), international students experience some social integration challenges common to migrant populations, as well as specific issues of integration at university (Zhou \& Zhang, 2014). Based on the contention that migrants' technology use after migration is necessarily influenced by the uses they developed prior to migration (Codagnone \& Kluzer, 2011), this article aims to draw a portrait of international students' use of technologies by examining this before and after migration, as well as by comparing these students to local students. In order to orient university policies and practices, this is a necessary initial step toward a more nuanced understanding of the role that technology plays in international students' university integration.

After presenting a brief profile of the international students considered, we problematize the relationship between technology use by international students and their integration into university. We then present our methodology and our results. We conclude with some implications for the university integration of international students. 


\section{Context}

We begin with a reminder of the potential role of technology in facilitating migrant integration, and examine this role as it relates to the university integration of international students.

\section{Technology use by migrants and social integration}

The flow of international migrants is currently estimated at 250 million (The World Bank, 2015). Considering the pervasiveness of technology in developed countries (and looking at this aspect alone), the successful integration of migrants requires technological integration, in addition to the social, political, and economic integration that the literature has traditionally addressed (Codagnone \& Kluzer, 2011; Ros, 2010). More specifically, technology provides access to official information (e.g., government websites) and informal information (e.g., networking websites), as well as various services, notably for employment (e.g., job search websites) and education (Kluzer, Haché, \& Codagnone, 2008). It can also facilitate migrant empowerment by providing migrants with a voice and making them visible, and by enabling them to establish a dialogue with the host society (e.g., diaspora websites) (Kluzer, Haché, \& Codagnone, 2008). On the other hand, it could be argued that lack of access to or inability to use technology are potential exclusion factors for migrants (Warschauer, 2003). In addition, an exploration of how migrants use technology could reveal whether this is a new form of exclusion or, on the contrary, a new way to create migratory resources (Nedelcu, 2009).

\section{Technology use by international students and implications for university integration}

Like other migrant categories, the number of international students is expanding rapidly. According to UNESCO (2014), in 2014, over 4.1 million students were enrolled in an educational program in a foreign country, a remarkable increase over the 1990s when there were approximately 2 million students, equivalent to a $6 \%$ increase per year (OECD, 2013). Canada was among the top ten destinations for foreign students in 2014, and its market share steadily increased between 1999 and 2014 (UNESCO, 2014). In 2015, the number of international students was estimated at 360,000 , or double the number ten years previously (Immigration, Refugees and Citizenship Canada, 2016). International students represent a significant strategic factor in the development of both universities and host countries. In economic terms, they generated \$30.5 million in the United States in 20142015 (NAFSA: Association of International Educators, n.d.). In Canada, international students boosted the Canadian economy by $\$ 8.4$ billion in 2012. For instance, they held at least 86,570 jobs and generated over $\$ 455$ million in federal and provincial tax revenues (Government of Canada, 2014). They also serve to fill the ranks of universities and spur scientific and technological competition in host countries. In addition, they make a key contribution to building international collaboration (Kapadia, 2016). Therefore, it is understandable that universities invest so much effort in attracting and retaining foreign students. (see Mazzarol, Soutar, \& Seng, 2003.)

As in the case of the social integration of migrants (see the section on Technology use by migrants and social integration), technology appears to be an influential factor in the university integration of international students, as access to and ability to use technology are important conditions for university integration (Karsenti \& Larose, 2001; Tian, Yu, Vogel, \& Kwok, 2011). They are likely to support both academic success (e.g., through the use of learning platforms such as Moodle, Internet searches, email communication with professors, and visits to the university Facebook page), and relationships (e.g., peer contact on Facebook, mobile phone and email, and information searches for student activities on student association websites). In this 
sense, technologies are an essential part of the academic and social integration of international students.

However, international students come from a wide range of countries, where technology use varies according to country-specific cultural, political, economic, and other factors (Collin \& Karsenti, 2012). Hence, it could be argued that when they arrive in the host country, many international students must adapt the way they use technologies, which may be more or less lengthy or arduous, in order to adjust to the host university's new academic and relational customs and demands. Based on the view that migrants' technology use after migration is necessarily influenced by the uses they developed prior to migration (Codagnone \& Kluzer, 2011), an exploration of technology use by international students must take into account their use of technology both before and after migration. However, few studies have addressed the particular case of international students' use of technology, particularly in comparison to local students, and the handful of studies that have considered young migrants have focused largely on the relationships they maintain with friends and family back home (see, e.g., Benítez, 2006; Gallant \& Friche, 2010), and not on the changes that the migration process has brought in their technology use.

\section{Objective}

The objective of this article is to depict international students' use of technologies. This constitutes a necessary first step toward a deeper understanding of the role of technology in the university integration of international students. To do so, we first compare international students' use of technology before and after migration, in order to identify changes in their technology use. We then compare their technology use after migration with those of local students, to distinguish the uses that are specific to international students from those common to all students.

\section{Methods}

We begin with a presentation of the participants of this study. We then describe the exploratory methodology employed.

\section{Participants}

The participants were 1,325 international students, as defined by their Canadian student visa and university status, and 251 local students, enrolled at two French-language universities in Québec (Canada), whose official language is French. As for the international students, $64 \%$ were from 18 to 24 years old and $60 \%$ were women. In comparison, only $51 \%$ of local students were between 18 and 24, and they were predominantly male (80\%). Among international students, $74 \%$ of the participants had lived in Canada for one year or less, $23 \%$ for from two to four years, and $3 \%$ for at least five years. $42 \%$ of them were enrolled in their first semester of university in Canada, $24 \%$ in their second or third semester, $14 \%$ in their fourth or fifth semester, and $9 \%$ in their sixth or seventh semester. Conversely, the majority of local students $(55 \%)$ had already completed six semesters or more at the university, as only $4 \%$ were registered in the first semester, $19 \%$ in the second, $6 \%$ in the third, $12 \%$ in the fourth and $5 \%$ in the fifth semester.

The majority of international students $(68 \%)$ came from Europe or North America, and $78 \%$ were native French-speakers, while $91 \%$ of local students have French as their first language. In addition, the majority of international students came from well-educated backgrounds: $37 \%$ had parents with college or undergraduate degrees and $43 \%$ had parents with master's or doctoral 
degrees. For local students, their parents' level of education is also high but relatively lower than that of international students: $57 \%$ had parents with a college or undergraduate level of education, while only $12 \%$ had parents with a master's degree or a doctorate.

In terms of their technology profile, international students had good digital skills: $46 \%$ claimed an average level of competency, while $46 \%$ felt more or much more competent than average. In other words, only $8 \%$ felt less or much less competent than average. The trend is similar for local students: $47 \%$ perceive themselves to be as competent and informed as the average student, and $44 \%$ feel more, or even much more, competent and informed than the average.

These perceptions appear to have been supported by the participants' experience in Internet use. Among international students, $37 \%$ began using it in elementary school and $50 \%$ in high school. So, they were already comfortable with the Internet prior to entering university. In comparison, local students are more likely to have started using the Internet in preschool and elementary school $(51 \%$ ), while $27 \%$ and $22 \%$ respectively began in high school or higher education (college and university).

In summary, the two subsamples have somewhat different profiles. International students were slightly younger than local students, but more importantly, included more women. In addition, their parents' education level is slightly higher than that of local students' parents. However, local students had completed more academic semesters than their international peers and started using the Internet earlier, although the perception of technological competence of the two subsamples was similar. Finally, the two subsamples had French as their primary language, in accordance with the official language of Québec and the two participating universities.

\section{Data collection}

To achieve our objective, we developed two questionnaires that, with the assistance of the registrars' offices, we sent online to all the international and local students enrolled at the two participating universities. For validation, the questionnaires were the object of face-to-face cognitive interviews (Desimone \& Le Floch, 2004; Helsper, Van Deursen, \& Eynon, 2015) with eight international students who were not included in the final sample. This enabled us to clarify certain points. We then conducted an online pilot test of 18 international students who had the opportunity to comment on the items and sections, allowing for a second round of questionnaire improvement.

Following the validation of the questionnaire for international students, we adapted the questionnaire for local students. The two questionnaires were quite similar and contained several sections, including two that have been used as part of this article. The first section addressed socio-demographic characteristics (e.g., gender, and age) and had some additional questions about migration for international students (e.g., the number of years residing in Canada as an international student). The second section addressed the students' use of technology. Three variables about technology use were included: a) the technologies they accessed (desktop, laptop, non-smartphone, smartphone, etc.), and the frequency they did so (every day, a few times a week, a few times a month, a few times a year, or never); b) the Internet access (at home, at university — outside of class, or at university — in class, etc.) available to them (with a "yes" or "no" response), and c) the activities (social networking, or watching) they carried out on the Internet (with a "yes" or "no" response). In the questionnaire for international students, all these questions were applied to the pre-migration period (i.e., before migration) and the post-migration 
period (i.e., after migration), in order to identify changes in technology use before and after migration.

\section{Data analysis}

Because there were so many more international than local students in our study $(1,325$ international students vs. 251 local students), we chose nonparametric tests.

To compare technology use by the international students before and after migration, we used the Wilcoxon Rank Test for the frequency of technology use and the McNemar test for matched pairs of data for Internet access and activities on the Internet. Thus, we were able to identify significant differences in the way international students used technology before and after migration.

To compare technology use by international students after migration with that of local students, we used the Mann-Whitney nonparametric sample test for frequency of technology use and the Chi-square $\left(\chi^{2}\right)$ test for Internet access and activities on the Internet. Thus, we were able to identify the significant differences between those two subsamples.

\section{Results}

Below, we begin by presenting the results of international students' technology use before and after migration. In a further analysis of these results, we compare their use of technology after migration with that of local students. In the discussion, we connect these results to the existing academic literature.

\section{Comparison of technology use before and after migration}

In this section, we begin by comparing the way international students use technology before and after migration, with a focus on significant differences, in order to identify the main technological changes that accompany the migration of international students. We begin by examining their frequency of access to technologies, their access to the Internet and the activities they carry out on the Internet.

\section{Technologies accessed before and after migration}

Table 1 makes it possible to specify variations in the frequency of access to technologies before and after migration, by presenting their average frequency (where $1=$ every day, $2=\mathrm{a}$ few times a week, $3=$ a few times a month, $4=$ a few times a year, and 5=never), their differential and statistical results from the Wilcoxon rank test. In this regard, it is interesting to note that the Internet, laptop computer and word processing software are the three technologies that international students report using most frequently before migration, with a frequency between 1 (every day) and 2 (a few times a week). This trend increases significantly after migration (laptop: $Z=9.71, p<.001$, Internet: $Z=8.92, p<.001$, and word processing software: $Z=11.32$, $p<.001)$. International students report that cell phones are the second most frequently used technology, with a frequency between 2 (a few times a week) and 3 (a few times a month) and here we see reverse trends: while the non-smart cell phone decreases significantly $(Z=5.99$, $p<.001)$ after migration, the smart cell phone increases marginally and not significantly, suggesting that most international students who report using it after migration already used it before migrating. Finally, the desktop computer and especially the tablet are the technologies that international students report using the least, with a frequency ranging from 3 (a few times a 
month) to 5 (never). They evolve differently before and after migration: while the desktop computer decreases significantly $(Z=6.03, p<.001)$, the tablet increases marginally and not significantly.

\section{Table 1}

Frequency of technology access before and after migration as measured by the average frequency of technology access (where 1 = every day, 2 = a few times a week, $3=$ a few times a month, $4=a$ few times a year, $5=$ never)

\begin{tabular}{lccc}
\hline Technologies accessed & \multicolumn{2}{c}{ Average frequency } & Differential between \\
\cline { 2 - 3 } & $\begin{array}{c}\text { before } \\
\text { migration }\end{array}$ & $\begin{array}{c}\text { after } \\
\text { migration }\end{array}$ & $\begin{array}{c}\text { migration } \\
\text { mignd after }\end{array}$ \\
\hline Word-processing software & 1.98 & 1.68 & $+0.30 * * *$ \\
Laptop & 1.34 & 1.14 & $+0.20 * * *$ \\
Internet & 1.15 & 1.03 & $+0.12 * * *$ \\
Tablet & 4.16 & 4.06 & +0.10 \\
Smartphone & 2.65 & 2.61 & +0.04 \\
Desktop computer & 3.09 & 3.26 & $-0.17 * * *$ \\
Non-smart phone (no Internet access) & 2.34 & 2.78 & $-0.44 * * *$ \\
\hline
\end{tabular}

$* p<.05 \quad * * p<.01 \quad * * * p<.001$

In summary, it appears that migration is accompanied by a slight increase in the overall frequency of access to technologies, ranging from an average of 2.39 before migration to 2.37 after migration (where $2=$ a few times a week and $3=$ a few times a month). The only access frequencies that decrease after migration are the most dated technologies (desktop computers, and non-smartphones), which seem to be replaced by their more recent equivalents (laptops, and smartphones) during migration.

\section{Internet access before and after migration}

Table 2 shows the percentage of participants accessing the Internet in different locations before and after migration, their differential, and the McNemar test results for matched pairs of data. Home was the main Internet access site reported by participants before migration (86.5\%), and this trend keeps increasing significantly after migration $\left(+10.2 \% ; \chi^{2}=81.48, p<.001\right)$. However, the parents' home $\left(\chi^{2}=568.79, p<.001\right)$ was the second most popular access place reported by international students before migration $(73.6 \%)$, and this decreases strongly and significantly to $26.1 \%$ after migration. The same trend applies, though to a lesser extent, to the homes of friends and neighbours $\left(\chi^{2}=8.64, p<.001\right)$ and the workplace $\left(\chi^{2}=39.08, p<.001\right)$, which went from $46 \%$ to $41.6 \%$, and from $32.8 \%$ to $28.6 \%$ respectively.

On the contrary, Internet access at university shows a considerable and significant rise after migration, becoming the second most popular Internet access site reported by participants: $80.4 \%$ of them had Internet access in the classroom $\left(+30.4 \% ; \chi^{2}=303.38, p<.001\right)$, and $73.8 \%$ outside the classroom $\left(+27.3 \% ; \chi^{2}=232.36, p<.001\right)$. Albeit secondary, public access and community and association sites increased significantly $\left(+19.9 \% ; \chi^{2}=175.06, p<.001\right)$ after migration, as did cybercafés $\left(+5.8 \% ; \chi^{2}=15.25, p<.001\right)$.

As in the case of frequency of access to technologies, access to the Internet increases after migration, going from an average of 4.37 access sites per participant before migration, to an average of 4.72 after migration. Although Internet access in the home of international students is 
the most popular, Internet connectivity from the university (in-class or out-of-class) is the one that shows the greatest variation following migration. However, the use of public places, community or associations' sites and cybercafés also increase after migration. Finally, the only Internet access points that decrease after migration are those related to the social network (at my parents' home; and at the homes of my friends and neighbours) and professional network (at work) of the home society.

\section{Table 2}

Internet access for participants before and after migration (in \%)

\begin{tabular}{|c|c|c|c|}
\hline \multirow[t]{2}{*}{ Internet access sites } & \multicolumn{2}{|c|}{$\%$ of participants } & \multirow{2}{*}{$\begin{array}{c}\text { Differential } \\
\text { between before and } \\
\text { after migration }\end{array}$} \\
\hline & $\begin{array}{c}\text { before } \\
\text { migration }\end{array}$ & $\begin{array}{c}\text { after } \\
\text { migration }\end{array}$ & \\
\hline At university, in class (e.g., with my laptop) & $50.0 \%$ & $80.4 \%$ & $+30.4 \% * * *$ \\
\hline At university, outside the classroom (e.g., in a computer lab) & $46.5 \%$ & $73.8 \%$ & $+27.3 \% * * *$ \\
\hline $\begin{array}{l}\text { In a public place or at a community group or association site } \\
\text { (e.g., public library) }\end{array}$ & $32.8 \%$ & $52.7 \%$ & $+19.9 \% * * *$ \\
\hline At my home & $86.5 \%$ & $96.7 \%$ & $+10.2 \% * * *$ \\
\hline In a cybercafé & $24.4 \%$ & $30.2 \%$ & $+5.8 \% * * *$ \\
\hline At my workplace & $32.8 \%$ & $28.6 \%$ & $-4.2 \% * * *$ \\
\hline At the homes of my friends or neighbours & $46.0 \%$ & $41.6 \%$ & $-4.4 \% * * *$ \\
\hline At my parents' home & $73.6 \%$ & $26.1 \%$ & $-47.5 \% * * *$ \\
\hline
\end{tabular}

\section{Activities on the Internet before and after migration}

To conclude the comparison between technological changes that occur before and after the migration of international students, we can now look at their activities on the Internet. Table 3 shows the percentage of participants involved in Internet activities before and after migration, their differential, and the McNemar test results for matched pairs of data. It is possible to distinguish three types of evolution of Internet activities before and after migration.

\section{Activities strongly present before migration and reinforced after migration}

Using email $\left(+1.8 \% ; \chi^{2}=35, p<.05\right)$, participating in social networking sites $(+2.5 \%$; $\left.\chi^{2}=19.82, p<.001\right)$, keeping informed on matters of personal interest $\left(+2.6 \% ; \chi^{2}=10.01\right.$, $p<.001)$, reading newspapers or magazines $\left(+4.3 \% ; \chi^{2}=139.99, p<.001\right)$ and downloading text, photos, images, music, etc. $\left(\chi^{2}=7.13, p<.05\right)$ are the main activities reported by a large number of participants (between $79.4 \%$ and $94.8 \%$ ) prior to migration. They all increase slightly (less than $5 \%$ ) but significantly later. These activities are, therefore, already strongly present before migration and reinforced after migration.

\section{Internet activities that were secondary before migration and strongly increase following migration}

Other activities, more secondary before migration, increase significantly after migration, in particular:

- $\quad$ in terms of university studies: using a digital environment for university studies $(+47.1 \%$; $\left.\chi^{2}=511.96, p<.001\right)$ and using the university website $\left(+36.9 \% ; \chi^{2}=385.88, p<.001\right)$; 
- in terms of communication: phoning, and making video calls $\left(+26.6 \% ; \chi^{2}=338.23\right.$, $p<.001)$;

- in terms of financial management: managing its finances $\left(+24.4 \% ; \chi^{2}=226.40, p<.001\right)$;

- in terms of media consumption: watching TV $\left(+10.9 \% ; \chi^{2}=30.95, p<.001\right)$, and looking for information on health, education, and services $\left(+9.0 \% ; \chi^{2}=44.00, p<.001\right)$;

- and on the level of socialization: planning cultural activities $\left(+10.8 \% ; \chi^{2}=58.78, p<.001\right)$.

\section{Secondary Internet activities before migration which are relatively stable after migration}

This category contains activities that have marginally increased (using a microblog or discussion forum to give one's opinion: $\chi^{2}=17.49, p<.001$; and looking for job offers or posting job applications) or decreased (chatting: $\chi^{2}=4.54, p<.05$; online shopping: $\chi^{2}=10.96, p<.001$; online gaming: $\chi^{2}=19.31, p<.001$; and listening to the radio).

\section{Table 3}

Activities on the Internet by participants before and after migration (in \%)

\begin{tabular}{|c|c|c|c|}
\hline \multirow[t]{2}{*}{ Activities on the Internet } & \multicolumn{2}{|c|}{$\%$ of participants } & \multirow{2}{*}{$\begin{array}{c}\text { Differential } \\
\text { between before and } \\
\text { after migration }\end{array}$} \\
\hline & $\begin{array}{c}\text { before } \\
\text { migration }\end{array}$ & $\begin{array}{c}\text { after } \\
\text { migration }\end{array}$ & \\
\hline Using a university digital learning environment & $40.9 \%$ & $88.0 \%$ & $+47.1 \% * * *$ \\
\hline Using the university website & $49.2 \%$ & $86.1 \%$ & $+36.9 \% * * *$ \\
\hline Phoning, making video calls & $59.7 \%$ & $86.3 \%$ & $+26.6 \% * * *$ \\
\hline Managing its finances & $63.0 \%$ & $87.4 \%$ & $+24.4 \% * * *$ \\
\hline Watching TV & $40.3 \%$ & $51.2 \%$ & $+10.9 \% * * *$ \\
\hline Planning cultural activities & $73.3 \%$ & $84.1 \%$ & $+10.8 \% * * *$ \\
\hline Looking for information on health, education, or services & $67.9 \%$ & $76.9 \%$ & $+9.0 \% * * *$ \\
\hline Reading journals, newspapers, magazines, etc. & $79.4 \%$ & $83.7 \%$ & $+4.3 \% * * *$ \\
\hline Keeping informed about personal interests & $81.9 \%$ & $84.5 \%$ & $+2.6 \% * * *$ \\
\hline Participating in social networking sites & $85.6 \%$ & $88.1 \%$ & $+2.5 \% * * *$ \\
\hline Sending and receiving emails & $94.8 \%$ & $96.6 \%$ & $+1.8 \% *$ \\
\hline Downloading text, photos, images, music, etc. & $79.7 \%$ & $81.5 \%$ & $+1.8 \% *$ \\
\hline Looking for job offers or posting job applications & $56.8 \%$ & $58.5 \%$ & $+1.7 \%$ \\
\hline Using a microblog or discussion forum to give one's opinion & $23.9 \%$ & $25.3 \%$ & $+1.4 \% * * *$ \\
\hline Listening to radio & $39.1 \%$ & $38.5 \%$ & $-0.6 \%$ \\
\hline Shopping online & $51.5 \%$ & $48.6 \%$ & $-2.9 \% * * *$ \\
\hline Chatting & $47.9 \%$ & $44.6 \%$ & $-3.0 \% *$ \\
\hline Playing online games & $27.8 \%$ & $23.8 \%$ & $-4.0 \% * * *$ \\
\hline
\end{tabular}

$* p<.05 \quad * * p<0.01 \quad * * * p<.001$

As with access to technology and the Internet, the migration of international students is accompanied by an increase in activities on the Internet, going from an average of 10.63 activities per participant before migration to an average of 12.42 after migration. 


\section{Comparison of technology use between international students and local students}

The previous section allowed us to document some of international students' technological changes following their migration. In order to deepen our understanding of the digital technology uses of international students, we have compared them with those of local students, to distinguish those that are specific to them from those that are shared by all university students, both international and local. This section focuses on the significant differences between the digital technology uses of international students after migration and those of local students in terms of access to technologies, Internet access and Internet activities.

\section{Access to technologies}

The nonparametric Mann-Whitney test indicates a significant difference between local and international students in the frequency of access to a desktop computer $(Z=6.804, p=.000)$, a laptop computer $(Z=9.168, p=.000)$, the Internet (on a computer) $(Z=3.335, p=.001)$, a tablet $(Z=4.212, p=.000$,$) and a non-smartphone (Z=4.108, p=.000)$. More specifically: local students report using a desktop computer and a tablet more often than international students. Conversely, the latter report using a laptop, Internet and mobile phone without Internet access more frequently than local students.

\section{Internet access}

A Chi square test indicates a significant difference between international and local students in access to the homes of relatives $\left(\chi^{2}(1, N=1446)=62.45, p=.000\right)$, access to the Internet in the workplace $\left(\chi^{2}(1, N=1446)=90.05, p=.000\right)$ and access to the Internet in public, community or voluntary association settings $\left(\chi^{2}(1, N=1446)=25.89, p=.000\right)$. While local students claim to have access to the Internet at their parents' home and in the workplace more often than international students, the latter are more likely to access it in public, community or voluntary sector settings.

\section{Activities on the Internet}

Finally, a Chi square test confirms that there is a significant difference between international and local students regarding the use of the Internet to make calls or make video calls $\left(\chi^{2}(1, N=1448)=206.90, \quad p=.000\right)$, to look for job offers or to apply for work $\left(\chi^{2}(1, N=1448)=47.30, p=.000\right)$, to shop online $\left(\chi^{2}(1, N=1448)=25.58, p=.000\right)$ and to give their opinion on a blog or discussion forum $\left(\chi^{2}(1, N=1448)=25.19, p=.000\right)$. Local students are more likely to use the Internet to look for work and for shopping, while international students report using the Internet to make phone calls or make webcam video calls and to give their opinion on blogs or discussion forums more than local students.

\section{Discussion and conclusion}

As a reminder, the purpose of this article was to paint a picture of international students' use of technology. In this section, we relate the two sets of previous results (changes in the use of technology among international students before and after their migration; and comparison of the digital technology uses of international students after migration with those of local students). In so doing, we also link them to the existing academic literature. 


\section{Between technological continuity and change}

A first notable point is that the migration of international students entails both technological continuity and change. In terms of continuity, certain communication activities (e.g., sending and receiving emails, participating in social networking sites), media consumption (e.g., reading journals, newspapers, and magazines, and downloading text, photos, images, music, etc.) and leisure (e.g., keeping informed about personal interests or reading newspapers, magazines, etc) were already strongly present before migration and are reinforced following migration. Others were stable (e.g., using a microblog or discussion forum to give one's opinion, looking for job offers or posting job applications) and some decreased (chatting, online shopping, online gaming, and listening to the radio). However, several changes occurred after migration which denote an overall increase in their use of technology.

\section{Technological changes attributable to the migration process}

The changes that occur seem to depend on several factors. One of them is attributable to migration and distinguishes international students from their local peers. The technological changes caused by migration appear to imply two different processes. The first is a replacement process. For example, in terms of the frequency of access to technology, the desktop computer and mobile phone without Internet access decreased sharply after migration and appeared to be replaced by the laptop and smartphone. In other words, migration appears to constitute an opportunity for international students to update their technologies, especially when the latter are not easily transported (i.e., desktop computer) or are outdated (i.e., a cell phone without Internet access).

The second process of technological change appears to be based on compensation and can take different forms.

1) Access to the Internet at the university and in the public, community or voluntary sector to compensate for the loss of access to the Internet at parents' homes: while the home connection remains by far the first access point, the connection to the Internet at the parents' home and the homes of friends and neighbours decreases sharply after migration and differs significantly from that of local students. It seems to be offset by a sharp increase in access to the Internet at university (both in and out of class) and, secondarily, in public, community or voluntary association settings and cybercafés. Thus, international students seem to experience a loss of family, friendship, and professional networks after migration, which would involve compensation phenomena by reconfiguring Internet access.

2) Communication by audio or video calls to compensate for loss of face-to-face communication: some communication activities (phoning, or making video calls with a webcam) increase after migration and distinguish international students from local students. The importance of audio and video calls is probably due to the need for international students to stay in touch with loved ones (family, and close friends) in the home society and to compensate for the loss of face-to-face interaction. On this topic, Licoppe $(2002,2004)$ distinguishes between two types of interactions enabling students to maintain ties with distant family and friends. The first type, conversational interaction, occurs less frequently but allows lengthier interactions via synchronous technologies (e.g., telephone, or Skype). The longer time enables speakers to maintain a shared store of experience that strengthens the relationship, despite the distance separating them. The second type, connected interaction, occurs via asynchronous channels (e.g., email, or texting), allowing shorter but more frequent 
communications. The aim is less to share information than to maintain a presence. On the basis of these two types of interaction, it is therefore conversational interaction which seems to distinguish international students from local students.

3) Use of the Internet to compensate for the lack of information about the host society: international students use the Internet significantly more frequently than local students. In addition to the fact that the Internet is an indispensable tool for every individual, it is particularly crucial for migrants insofar as it allows them to access information and make decisions to compensate for their lack of knowledge of the host society (Caidi, Allard, \& Dechief, 2010), which may explain why international students use it more frequently.

\section{Technological changes attributable to student life}

In addition to the technological changes attributable to the migration process, some other changes appear to be due to student life in general and university studies in particular, and are valid for all students, whether local or international. For example, although the smartphone is by far the preferred technology of migrants before, during and after migration (Madianou, 2014), it is interesting to note that it is used less frequently by the international students of our study than the laptop, Internet and word processing software. This may be due to their status as university students, which implies specific working tools that may distinguish them from other categories of migrants. This can also explain why some of their particular university activities, such as using a digital environment for university studies and using the university website, do not differ from those of local students. However, it is interesting to note that international students are still more likely to use a non-smart cell phone and have used a tablet less frequently than local students, which may suggest that they are accessing relatively less recent technologies than local students, even after migration.

\section{Avenues for future research}

Because they are preliminary, these results still need to be explored further. In this regard, an obvious limitation of this study is that it is based on an online questionnaire, which poses the usual issues of self-selection and self-reporting (Hargittai, 2010) but has the advantage of reaching a large number of participants. In this sense, the results obtained are not generalizable because they are likely to represent particular profiles of international and local students rather than others. In addition, both subsamples show some differences in sociodemographic and technological profile. Since we have not controlled for them, they may constitute possible biases. On the basis of these limitations, it would therefore be necessary to carry out: 1) research taking into account the possible diversity of profiles of international students; and 2) qualitative research, considering the broader environment, which is likely to be part of the university integration experience, in order to reveal the perceptions and the underlying logics at work in international students' technological uses. Furthermore, it would be interesting in future studies to go beyond description and to examine the effects of technological uses on the quality of international students' academic and social integration.

\section{References}

Benítez, J. L. (2006). Transnational dimensions of the digital divide among Salvadoran immigrants in the Washington DC metropolitan area. Global Networks, 2(6), 181-199. doi:10.1111/j.1471-0374.2006.00140.x 
Caidi, N., Allard, D., \& Dechief, D. (2010). Information practices of immigrants to Canada: A review of the literature. Ottawa: Citizenship and Immigration Canada.

Codagnone, C., \& Kluzer, S. (2011). ICT for the social and economic integration of migrants into Europe [study report]. Luxembourg: Publications Office of the European Union. https://doi.org/10.2791/53261

Collin, S., \& Karsenti, T. (2012). Facilitating linguistic integration of immigrants: An overview of ICT tools. Issues in Informing Science and Information Technology, 9, 243-251. https://doi.org/10.28945/1619

Desimone, L. M., \& Le Floch, K. C. (2004). Are we asking the right questions? Using cognitive interviews to improve surveys in education research. Educational Evaluation and Policy Analysis, 26(1), 1-22. Retrieved from CiteSeerX: http://citeseerx.ist.psu.edu

Gallant, N., \& Friche, C. (2010). Être ici et là-bas tout à la fois : réseaux sociaux en ligne et espaces d'appartenance chez les jeunes immigrants au Québec. Lien social et politiques, 2010(64), 113-124. https://doi.org/10.7202/1001403ar

Government of Canada. (2014). Canada's international education strategy. Retrieved from Global Affairs Canada website: http://international.gc.ca

Hargittai, E. (2010). Digital na(t)ives? Variation in Internet skills and uses among members of the "Net Generation." Sociological Inquiry, $80(1), \quad 92-113$. https://doi.org/10.1111/j.1475-682X.2009.00317.x

Helsper, E. J., Van Deursen, A. J. A. M., \& Eynon, R. (2015). Tangible outcomes of Internet use. From digital skills to tangible outcomes project report. Retrieved from Department of Media and Communications, London School of Economics and Political Science (LSE) website: http://lse.ac.uk/media-and-communications

Immigration, Refugees and Citizenship Canada. (2016, June). Immigration, Refugees and Citizenship Canada: Federal update [Slide presentation]. Presented at the British Columbia Council for International Education, Victoria, Canada. Retrieved from the Council website: http://bccie.bc.ca

International (or internationally mobile) students. (n.d.). In Glossary of the UNESCO Institute for Statistics. Retrieved August 1st, 2017 from http://uis.unesco.org

Kapadia, K. (2016, July 19). How international students are keeping US colleges afloat and powering the tech industry. Retrieved from http://techcrunch.com

Karsenti, T., \& Larose, F. (Eds.). (2001). Les TIC... au coeur des pédagogies universitaires. Québec, Canada: Presses de l'Université du Québec.

Kluzer, S., Haché, A., \& Codagnone, C. (2008). Overview of digital support initiatives for/by immigrants and ethnic minorities in the EU 27. Luxembourg: Office for Official Publications of the European Communities. https://doi.org/10.2791/58447

Licoppe, C. (2002). Sociabilité et technologies de communication: deux modalités d'entretien des liens interpersonnels dans le contexte du déploiement des dispositifs de communication mobiles. Réseaux, 2012/2-3(112-113), 172-210. https://doi.org/10.3917/res.112.0172 
Licoppe, C. (2004). "Connected" presence: The emergence of a new repertoire for managing social relationships in a changing communication technoscape. Environment and Planning D: Society and Space, 22(1), 135-156. doi:10.1068/d323t Retrieved from the author's ResearchGate profile: http://researchgate.net/profile/Christian_Licoppe

Madianou, M. (2014). Smartphones as polymedia. Journal of Computer Mediated Communication, 19(3), 667-680. https://doi.org/10.1111/jcc4.12069

Mattelart, T. (2009). Les diasporas à l'heure des technologies de l'information et de la communication: petit état des savoirs. tic\&société, 3(1-2). https://doi.org/10.4000/ticetsociete.600

Mazzarol, T., Soutar, G. N., \& Seng, M. S. Y. (2003). The third wave: Future trends in international education. International Journal of Educational Management, 17(3), 90-99. doi:10.1108/09513540310467778 Retrieved from T. Mazzarol's ResearchGate profile: http://researchgate.net/profile/Tim_Mazzarol

NAFSA: Association of International Educators. (n.d.). International student economic value tool. Retrieved August 24, 2016 from http://www.nafsa.org

Nedelcu, M. (2009). Du brain drain à l'e-diaspora: vers une nouvelle culture du lien à l'ère du numérique. tic\&société, 3(1-2). https://doi.org/10.4000/ticetsociete.675

OECD. (2013). Education at a glance 2013: OECD Indicators. Retrieved from http://oecd.org

Rigoni, I. (2010). Éditorial - Les médias des minorités ethniques: représenter l'identité collective sur la scène publique. Revue européenne des migrations internationales, 26(1), 7-16. Retrieved from http://journals.openedition.org/remi

Ros, A. (2010). Interconnected immigrants in the information society. In A. Alonso \& P. Oiarzabal (Eds.), Diasporas in the new media age: Identity, politics, and community (pp. 19-39). Reno, NV: University of Nevada Press.

The World Bank. (2015, December 18). International migration at all-time high [Press release]. Retrieved from http://worldbank.org

Tian, S. W., Yu, A. Y., Vogel, D., \& Kwok, R. C. W. (2011). The impact of online social networking on learning: A social integration perspective. International Journal of Networking and Virtual Organisations, 8(3-4), 264-280. doi:10.1504/IJNVO.2011.039999 Retrieved from S. W. Tian's ResearchGate profile: http://researchgate.net/profile/Wen_Stella_Tian

UNESCO. (2014). Global flow of tertiary-level students. Retrieved August 24, 2016 from http://uis.unesco.org

Warschauer, M. (2003). Technology and social inclusion: Rethinking the digital divide. Cambridge, MA: MIT Press.

Zhou, G., \& Zhang, Z. (2014). A study of first year international students at a Canadian university: Challenges and experiences with social integration. Comparative and International Education, 43(2), article 7. Retrieved from http://ir.lib.uwo.ca/cie-eci 